\title{
Opinion Paper: Forest management and biodiversity
}

\author{
E. D. Schulze ${ }^{1}$, L. Bouriaud ${ }^{2}$, H. Bussler ${ }^{3}$, M. Gossner ${ }^{4}$, H. Walentowski ${ }^{3}$, D. Hessenmöller ${ }^{5}$, \\ O. Bouriaud ${ }^{6}$, and K. v. Gadow ${ }^{7}$ \\ ${ }^{1}$ Max Planck Institute for Biogeochemistry, P.O. Box 100164, 07701 Jena, Germany \\ ${ }^{2}$ University Stefan cel Mare of Suceava, 13 University Street, 720229 Suceava, Romania \\ ${ }^{3}$ Bavarian State Inst. of Forestry, Hans-Carl-von-Carlowitz-Platz 1, 85354 Freising, Germany \\ ${ }^{4}$ Tech. Univ. Munich, Dept. of Ecology and Ecosystem Management, Hans-Carl-von-Carlowitz-Platz 2, \\ 85354 Freising, Germany \\ ${ }^{5}$ Käbach 13A, 98574 Schmalkalden, Germany \\ ${ }^{6}$ Forest Research and Management Institute, Bucharest, 128 Bd Eroilor, Voluntari, Romania \\ ${ }^{7}$ University of Göttingen, Romstr. 3a, 37079 Göttingen, Germany \\ Correspondence to: E. D. Schulze (dschulze@bgc-jena.mpg.de)
}

\begin{abstract}
In this opinion paper we investigate the effects of forest management on animal and plant biodiversity by comparing protected areas with intensively and extensively managed forests in Germany and in Romania. We want to know the extent to which differences in diversity of Romanian compared to German forests are based on management.

The number of tree species was not different in protected and managed forests ranging between 1.8 and 2.6 species per plot in Germany and 1.3 and 4.0 in Romania. Also herbaceous species were independent of management, ranging between 13 species per plot in protected forests of Romania and 38 species per plot in German coniferous forest. Coarse woody debris was generally low, also in protected forests (14 to $39 \mathrm{~m}^{3} \mathrm{ha}^{-1}$ ). The main difference between Romania and Germany was the volume of standing dead trees ( 9 to $28 \mathrm{~m}^{3} \mathrm{ha}^{-1}$ for Romania), which resulted in larger numbers of forest relict saproxylic beetles independent of management. Large predators (wolves, bears and lynxes) are only found in regions with low human intervention. Thus, we identified a "cut and leave" type of management in Romania, in which clear-felling of forest are followed by long periods of no human intervention. Forests managed in the "cut and leave" mode contained the highest diversity, due to a natural succession of plant species and due to habitat continuity for animals. In Germany intensive management eliminates poorly formed tree individual and species of low market value during stand development. Forest protection does not ensure the maintenance of more light demanding key species of earlier stages of succession unless competition by shade-tolerant competitors is reduced through disturbances.

We compare the economics of intensive and extensive management. The "cut and leave" mode delivers less wood to the wood market, but saves expenses of tending, thinning and administration. Thus the net income could be quite similar to intensive management at a higher level of biodiversity.

Our analysis suggests that forest protection per se does not yet ensure the maintenance of species. Clearfelling followed by natural succession may even be superior to the protection of old growth forests, regarding biodiversity. Further research is needed to substantiate this hypothesis.
\end{abstract}

\section{Introduction}

Forest management has affected forest composition in many very different ways (Küster, 2008). Historically, periodic and intensive biomass use created considerable tree species diversity in coppiced forests. This is in contrast to modern high forests of Picea or Fagus that exhibit extensive loss of tree species (Lüpke et al., 2011). Unlike the tree component of the forest ecosystem, management-related disturbances, nitrogen deposition and liming have caused an increase in diversity of the herbaceous forest flora in Germany, where herbs and grasses are in fact more diverse in managed forests 
than they are in protected areas (Boch et al., 2013; Reif et al., 2014; Schmidt, 2000). The effects of management on other organisms are largely unknown. Paillet et al. (2009) suggested a higher species richness of organisms occurs in the protected rather than the managed forests of Europe, even though several studies found either no difference in species richness in forests managed at different intensities (e.g., Müller et al., 2007, for saproxylic beetles, fungi and birds), or even the highest species richness occurring in intensively managed spruce plantations (e.g., Finch, 2005, for spiders).

It is a general observation that central Europe is impoverished in biodiversity when compared for instance with southeastern Europe, and especially with the Carpathian region. Thus, a comparison between central and southeast Europe could help us to understand effects of management and history. The Carpathian Mountains were a refuge for species in the Pleistocene, and therefore this region could have maintained a higher species reservoir than other regions just by its floral history. However, it is not clear to what extent forest history alone or forest management has contributed to the present-day observation that forests are more diverse in plant species and structure in the Carpathians, such as in Romania and Ukraine, as compared to Germany and Switzerland (Commarmot et al., 2005; Schulze et al., 2013). When focusing on arthropods the relationship between glacial refuges and biodiversity becomes even more questionable. For saproxylics, which are highly dependent on dead wood structures, a higher species and functional richness has been demonstrated in the Carpathians (Bussler and Müller, 2006; Gossner et al., 2013; Müller et al., 2005) even though species richness of other guilds does not necessarily follow this pattern (Chumak et al., 2005). One problem is that there are no ecosystems across Europe that are truly pristine. All ecosystems have been directly or indirectly affected by humans either to provide a particular mix of services and benefits, or by air pollution. Particular management activities have provided products and cash flow (Pukkala, 2008), water resources (Bosch and Gadow, 1990), erosion protection (Dragoi and Ciornei, 2013) and biodiversity (Aravind et al., 2005). Taking Fagus forests as an example, Schulze et al. (2010) demonstrated that forest management has affected forest biodiversity in Germany over centuries, changing landscapes from being highly biodiverse ecosystems to being very biodiversity-poor.

The objective of this contribution is to encourage a debate about forest conservation versus forest use for preserving biodiversity. This debate cannot be resolved without new comprehensive and comparative transnational data. However, the topic is sufficiently important to warrant discussion and more detailed studies in the future. Our main hypothesis is that differences in management practice have contributed to the observed differences in diversity of central versus southeastern Europe.

\section{Forest management in Germany and Romania}

\subsection{Terminology}

The basis of comparison will be the age-class or rotation forest, which is characterized by even-aged stands in different stages of development. Tree planting or natural regeneration is followed by a juvenile thicket stage, a period of stem growth and a final harvest when the rotation age is reached.

The sustainable management paradigm has emphasized interventions in the early stages of stand development. Tending and thinning operations are even prescribed by law in public and private forests in many nations. Rotation forestry is widespread across Europe, but different nations employ different management intensities.

In extensively managed age-class forests, tree survival is regulated by competition and self-thinning, and the forest is clear-felled when the trees reach commercial size. Replanting may or may not then take place after the final harvest, depending on whether natural regeneration occurs or not. This management practice has also been internationally described as "cut and run", a term referring to an unsustainable practice (FAO, 1999) associated with resource depletion and leading towards land-use change (Glastra, 1999). On a more sustainable level in which land is being kept as forest, we would like to conceptualize a management type termed "cut and leave", management that would not result in resource depletion. The "cut and leave" management includes clear-felling on limited areas, possible re-planting, but then minimal or no human intervention for the remaining rotation cycle.

In contrast, intensively managed age-class forest would start with natural regeneration under the shelter of the previous tree generation. The stands are tended at a thicket stage, followed by decadal thinning and a final harvest.

We are aware that the silvicultural terminology includes a great variety of additional management regimes and concepts (Burschel and Huss, 2003). However, to test our hypothesis we will focus on only three management types:

a. intensive age-class forest management or rotation forest management with periodic thinning (Germany),

b. extensive age-class forest management without thinning (cut and leave: Romania),

c. protected forest where any type of harvest is forbidden (note that protection is also a kind of management) and where nature is kept for "nature for its own sake" (Germany and Romania).

In nature conservation there is also the category of protection forest, in which normal forest operations are not banned, because the woodland serves as a habitat for species worthy of protection, such as the lady's slipper orchid (Cypripedium calceolus). 


\section{Forest management in Germany and Romania}

Forest management in Germany is specified in silvicultural regulations, as for instance by the Federal State of Thuringia (Waldbaurichtlinien, 2004). Forest properties of more than 30 ha require a decadal management plan, which specifies stand volumes, growth and wood extraction. Forest management starts by regulating the tree species mixtures during tending at the thicket stage. Decadal thinning operations follow. Eventually the stand is harvested. In these operations most succession species and poorly formed stems are excluded as early as possible to favor the preferred main tree species in its best form for commercial use. The anticipated tree density of commercial trees is about 1500 trees ha $^{-1}$ in young stands. Thinning reduces stand density to 80 to 100 trees ha $^{-1}$ of possibly high value at the time of final harvest. Clear-felling is prohibited. The new stand regenerates under shelter of the old stand. There is a permanent forest cover.

To a large extent, forest management in Romania may be characterized as "cut and leave". Even though tending and thinning are compulsory by law just as in Germany, the obligation to undertake tending and thinning can be neglected by the forest managers if there are good reasons. For example, even though most forests can be reached by steel cable for harvest, they cannot be reached for tending and thinning due to the lack of infrastructure (roads and lack of modern forest harvesting technologies). Aside from these logistic limitations, there is an additional important restriction in Romania, stating that forests can only be thinned until age 75. A "dead period" of $25 \mathrm{yr}$ follows without any intervention, until the stand is ready for harvest by law, but even then only a fraction of the total stand can be taken per decade. Thus, the final cut may be at age 160 for a nominally $100 \mathrm{yr}$ rotation, including a $25 \mathrm{yr}$ period of no cut.

Historically these rules were not followed during the communist era, when forests were over-harvested for the payment of war debts (1951-1955), for the development of the timber industry (1962-1975), and in an effort to cover the external Romanian debt (1981-1985) (Popescu et al., 2004). Additionally, after 1990, the restitution of private landownership was followed by irregular and illegal cuttings resulting in repeated severe wind throws and insect outbreaks. Large areas remained without replanting. Thus, clear-cutting has been practiced on a large scale during the last $100 \mathrm{yr}$ with clear-cuts being left for succession without systematic tending or thinning. The legal rules (Forest Code, 2008) for harvesting allow the harvesting of principal products (final cut), secondary products (from thinning and tending), accidental products (tree damaged by insects or wind) and sanitary cutting (dead trees). However, in forests without a forest management plan (e.g., private forests of less than $100 \mathrm{ha}$ ), and in forests that are subject to a protection status, harvesting was regulated to remain at maximum volume of about $1 \mathrm{~m}^{3}$ per hectare per year to control insect outbreak and wind damage (sanitary cutting). In reality, even groups of trees that may be killed by bark beetle cannot be extracted in the absence of access roads, even though the sanitary cutting system contains an opportunity also to cut valuable trees together with the damaged ones illegally. Thus, even when considering illegal logging as associated with small tree extractions for domestic purposes, the result is a minimum of human interference for decades over large areas of Romania. In this "cut and leave" environment, small-dimensioned poorly formed and rotten trees remain until final harvest. In addition, targeting the best trees during thinning and during sanitary cuts, if they took place, results in a situation that may be described as "cut the best and leave" with a remaining stand that is no longer saleable due to its stem forms. It will remain untouched by forest operations for decades or centuries.

The present forest use of Romania has been repeatedly criticized. Especially the very large clear-cuts in northeast Romania were supposed to have negative effects on biodiversity. Greenpeace (2010) estimated that on average 28000 ha of forest in Romania were subject to "deforestation" each year for the period 2000-2011. If the clear-felling area exceeds the distance of seed dispersal of anticipated tree species, clear-cuts could have negative effects. Therefore, Greenpeace also labeled final harvests as "deforestation" (Greenpeace, 2000). Legally, in Romanian forest law clearfelling of up to 3 ha is permitted for Norway spruce- and pine-dominated stands. Even though reforestation by planting is required by law, a successional tree cover emerges on clear-cut areas, which is usually dominated by birch or willow. Spruce (Picea abies) and beech (Fagus sylvatica) regenerate under shelter of early successional species.

In contrast to coniferous forests in both regions, broadleaved forests are generally managed by shelterwood cutting in which the canopy is opened in an initial cut to promote regeneration, and finally harvested after regeneration has been established. The young forest is again dominated by successional species, such as birch and poplar admixed with conifers and commercially valuable species, such as sycamore (Acer pseudoplatanus) and lime (Tilia tomentosa), which are eventually overgrown by the late successional $\mathrm{Fa}$ gus.

In the following we compare data from Germany (Alb, Hainich, Thüringer Wald), including the Hainich National Park and other areas under total protection (e.g., Keula; see Schulze et al., 2013). In Romania, the study is based on a grid-based inventory of the mountain forest zone, and of national parks (Semenic, Rodna, Piatra, Craiului). For more detailed studies, an inventory was made of a 500 ha forest at Boisoara on a grid basis (Walentowski et al., 2013). Here we compare Fagus forests in the montane zone (400 to $700 \mathrm{~m}$ above sea level) in Romania and in Germany, and Picea forests above $700 \mathrm{~m}$ elevation in Romania with Picea plantations in the Fagus zone in Germany.

The main hypothesis is that Romanian forest management differed from German due to the following reasons: 
Table 1. Comparative species numbers in differently managed forests of Germany and Romania. The plant data are based on $500 \mathrm{~m}^{2}$ inventory rings for trees and on $100 \mathrm{~m}^{2}$ plots for herbaceous plants. The data are averages over 4771 plots in Romania and 1924 plots in Germany focusing on the montane zone of Fagus and Picea forest (400 to $1000 \mathrm{~m}$ elevation). The German data refer to Thuringia; the Romanian data represent the whole nation. For birds, the comparison is based on three research areas of about $10 \times 20 \mathrm{~km}$ in Germany, and one 500 ha intensive study area in Romania. Large predators are based on a national count in Romania, and on Thuringia in Germany. Sources: 1: Schulze et al. (2013), 2: Hermannsberg, Hainich and Boisoara inventory, Romanian National Forest Inventory, E. D. Schulze, personal communication, 2013, 3: Boch et al. (2013), 4: A. Indreica, personal communication, 2013, 5: Bussler and Müller (2006), Müller et al. (2005), 6: Renner et al. (2013), 7: Walentowski et al. (2013).

\begin{tabular}{|c|c|c|c|c|c|c|c|}
\hline & & \multicolumn{2}{|c|}{ Forest type } & \multicolumn{4}{|c|}{ Number of species/plot or region, volume/hectar } \\
\hline & Plot area $\left(\mathrm{m}^{2}\right)$ & Management & Leaf type & Germany & Romania & Source-D & Source-R \\
\hline \multirow[t]{3}{*}{ Trees species } & \multirow[t]{3}{*}{500} & protected & deciduous & $2.6 \pm 1.2$ & $4.0 \pm 2.1$ & 1 & 1 \\
\hline & & age-class & deciduous & $1.8 \pm 0.9$ & $2.8 \pm 1.7$ & 1 & 1 \\
\hline & & age-class & coniferous & $1.8 \pm 1.0$ & $1.3 \pm 0.6$ & 2 & 2 \\
\hline \multirow{3}{*}{$\begin{array}{l}\text { Herb and grass } \\
\text { species }\end{array}$} & \multirow[t]{3}{*}{100} & protected & deciduous & $21.9 \pm 12.3$ & $13.4 \pm 7.8$ & 3 & 4 \\
\hline & & age-class & deciduous & $26.2 \pm 15.0$ & $32.0 \pm 14.4$ & 3 & 4 \\
\hline & & age-class & coniferous & $38.1 \pm 17.3$ & $20.0 \pm 8.7$ & 3 & 4 \\
\hline \multirow{3}{*}{$\begin{array}{l}\text { Coarse } \\
\text { woody debris } \\
\left(\mathrm{m}^{3} \mathrm{ha}^{-1}\right)\end{array}$} & \multirow[t]{3}{*}{500} & protected & deciduous & $38.8 \pm 69.1$ & $21.0 \pm 37.4$ & 2 & 2 \\
\hline & & age-class & deciduous & $18.3 \pm 32.5$ & $13.9 \pm 12.4$ & 2 & 2 \\
\hline & & age-class & coniferous & $23.1 \pm 29.3$ & $25.0 \pm 73.7$ & 2 & 2 \\
\hline \multirow{3}{*}{$\begin{array}{l}\text { Standing } \\
\text { dead wood } \\
\left(\mathrm{m}^{3} \mathrm{ha}^{-1}\right)\end{array}$} & \multirow[t]{3}{*}{500} & protected & deciduous & $13.0 \pm 19.2$ & $28.0 \pm 40.6$ & 2 & 2 \\
\hline & & age-class & deciduous & 0 & $9.4 \pm 2.1$ & 2 & 2 \\
\hline & & age-class & coniferous & 0 & $25.3 \pm 30.0$ & 2 & 2 \\
\hline Large predators & region & & & 0 & 3 & 1 & 1 \\
\hline Forest relict carabids & region & & & 4 & 15 & 5 & 5 \\
\hline Birds & plot to region & & & 10 & 46 & 6 & 7 \\
\hline
\end{tabular}

(1) the historical experience with large-scale clear-felled areas, (2) the low intensity of thinning and tending in the early stand stages, and (3) the length of the period without human intervention before the final cut. We are aware that our observational design remains unbalanced since we do not have stands of the "cut and leave" type in Germany nor of the intensively managed type in Romania.

\section{Biodiversity in Fagus and Picea forests}

On a regional average (4771 inventory plots in Romania and 1924 inventory plots in Germany), tree species diversity appears to be higher in Romanian age-class forests than in Germany (Table 1) except for conifers. Tree species diversity was slightly higher in protected forests than in deciduous or coniferous age-class forests. However, this may very well result from a bias towards protection of sites with higher diversity; the newly founded Jiului national park may serve as an example.

In the herbaceous layer the species richness was highest in German coniferous forests with about twice as many species as the Romanian Picea forest. The high herbaceous diversity in German coniferous forests could result from modern harvesting technology (invasion of ruderal species: Boch et al., 2013), as well as from liming operations and associated nitrogen saturation (Reif et al., 2014). Deciduous age-class forests had similar herbaceous diversity in Germany and Romania (Schmid, 2000), and the diversity of herbaceous plants of managed forests was generally higher than in protected forests.

Coarse woody debris resulting from thinning operations in Germany and from fallen dead trees in Romania was quite similar in coniferous and deciduous forest. The coarse woody debris was not higher in protected than in managed forests in Romania. The apparently higher coarse woody debris in German protected forest was not significant. A main difference emerged with standing dead wood, which is rare in German managed forests (Meyer and Schmidt, 2011) because of work-safety regulations, but it is common in Romania. In addition, standing dead wood debris and coarse woody debris are very patchy in Romania, and reach up to $600 \mathrm{~m}^{3} \mathrm{ha}^{-1}$ on small scale due to the missing infrastructure for sanitary cuttings.

Based on these management differences, the Romanian forest maintains the complete range of large predators, including wolves, bears and lynxes (Table 1). Even though deer populations are low in Romania, deer browsing may be observed for Acer species and bark peeling for Abies alba, as in Germany. 
Table 2. Estimated costs and revenues for hypothetical intensive and extensive Fagus and Picea age-class forests in Germany. The costs and revenues are based on data in Thuringia of year 2013, disregarding the cost of capital estimates. The cost of final harvest in Picea is lower than in Fagus because more manual work is required with Fagus. Picea operations are less expensive. The volume estimates are based on Thuringia and on Boisoara forest (Walentowski et al., 2013). The net income is highlighted by bold numbers. The comparison does not consider interest rates.

\begin{tabular}{|c|c|c|c|c|c|c|c|c|c|c|}
\hline \multirow[b]{2}{*}{ Operation } & \multicolumn{6}{|c|}{ Picea-permanent cropping } & \multicolumn{4}{|c|}{ Picea-cut and leave } \\
\hline & $\begin{array}{l}\text { Wood } \\
\text { volume } \\
\mathrm{m}^{3} \mathrm{ha}^{-1}\end{array}$ & $\begin{array}{l}\text { Harvesting } \\
\text { cost }\left(€ \mathrm{~m}^{-3}\right)\end{array}$ & $\begin{array}{l}\text { Total } \\
\text { cost } \\
\left(€ \mathrm{ha}^{-1}\right)\end{array}$ & $\begin{array}{l}\text { Sales } \\
\text { income } \\
\left(€ \mathrm{~m}^{-3}\right)\end{array}$ & $\begin{array}{l}\text { Total } \\
\text { income } \\
\left(€ \mathrm{ha}^{-1}\right)\end{array}$ & $\begin{array}{l}\text { Net } \\
\text { income } \\
\left(€ \mathrm{ha}^{-1}\right)\end{array}$ & $\begin{array}{l}\text { Wood } \\
\text { volume } \\
\mathrm{m}^{3} \mathrm{ha}^{-1}\end{array}$ & $\begin{array}{l}\text { Total } \\
\text { cost } \\
\left(€ \mathrm{ha}^{-1}\right)\end{array}$ & $\begin{array}{l}\text { Total } \\
\text { income } \\
\left(€ \mathrm{ha}^{-1}\right)\end{array}$ & $\begin{array}{l}\text { Net } \\
\text { income } \\
\left(€ \mathrm{ha}^{-1}\right)\end{array}$ \\
\hline Tending & 50 & & 500 & & 0 & -500 & 0 & 0 & 0 & O \\
\hline Thinning & 300 & 20 & 6000 & 70 & 21000 & 15000 & 0 & 0 & 0 & 0 \\
\hline Final harvest & 250 & 18 & 4500 & 80 & 20000 & 15500 & 500 & 9000 & 40000 & 31000 \\
\hline $\begin{array}{l}\text { Machine } \\
\text { tracks }\end{array}$ & 60 & 20 & 1200 & 70 & 4200 & 3000 & 0 & 0 & 0 & $\mathbf{0}$ \\
\hline \multirow[t]{2}{*}{ Total } & 610 & & 12200 & & 45200 & 33000 & 500 & 9000 & 40000 & 31000 \\
\hline & \multicolumn{6}{|c|}{ Fagus - permanent cropping } & \multicolumn{4}{|c|}{ Fagus - cut and leave } \\
\hline Tending & 50 & & 500 & & 0 & -500 & 0 & 0 & 0 & $\mathbf{0}$ \\
\hline Thinning & 300 & 20 & 6000 & 40 & 12000 & 6000 & 0 & 0 & 0 & 0 \\
\hline Shelter & & 20 & 4000 & 50 & 10000 & 6000 & 400 & 8000 & 20000 & 12000 \\
\hline Final harvest & 200 & 20 & 1000 & 50 & 2500 & 1500 & 100 & 2000 & 5000 & 3000 \\
\hline $\begin{array}{l}\text { Machine } \\
\text { tracks }\end{array}$ & 50 & 20 & 1200 & 50 & 3000 & 1800 & 0 & 0 & 0 & $\mathbf{0}$ \\
\hline Total & 600 & & 12700 & & 27500 & 14800 & 500 & 10000 & 25000 & 15000 \\
\hline
\end{tabular}

Standing dead wood and methuselah trees provide habitats for numerous xylobiontic beetles (Walentowski et al., 2013; Bussler et al., 2005). Thus, forest relic carabids are much more abundant in Romania than in Germany. Taking the Coleoptera as an example, we found 11 "rare" species on a 500 ha Picea and Fagus forest, which was managed in a "cut and leave" mode (Walentowski et al., 2013). This contrasts to Germany, where relict species of Coleoptera are rare on a regional scale (Bussler and Müller, 2006). An example for formerly heavily used forest and a high coleopteran diversity at present times may be the Jiului Valley in Romania, which was clear-cut and burnt with remnants of old trees still present before it became a national park due to its diversity of Coleoptera (Bussler et al., 2005). Over 30 endangered and rare species were documented. Seven species are even listed in Appendix II of the Fauna Flora Habitat Directive (92/43/EWG): Rhysodes sulcatus (F., 1787), Сисиjus cinnaberinus (Scop., 1763), Osmoderma eremita (Scop., 1763), Lucanus cervus (L., 1758), Rosalia alpina (L., 1758), Cerambyx cerdo (L., 1758) and Morimus funereus (Muls., 1863). Endangered species co-occurred on the same tree that has not been observed in Germany (e.g., Rosalia alpina and Lucanus cervus). Thus, the abundance of species on a very small scale was most remarkable in the formerly heavily used Jiului forest.

Also the Romanian forests contain a more diverse bird population (Walentowski et al., 2013) with species that are basically extinct in Germany (e.g., Tetrao urogallus). Butterflies and nocturnal moths are abundant and very diverse (not listed in Table 1), containing species that are rare in Germany and are generally not typical for forests (e.g., Nymphalis polychloros, Hacker, 1998).

The higher diversity of butterflies and canopy-living insects in Romania is most likely related to the higher diversity of tree species and of shrubs (Walentowski et al., 2010; Schulze et al., 2013). It was shown that different insect species require individual hosts, and not all tree species are equal in supporting biodiversity. In this context the early successional species, such a Salix, which disappears in German forests with tending, supports an outstanding diversity of butterflies (Brändle and Brandl, 2001). Thus the conditions supporting a high organismic diversity are not the old growth conditions but the younger successional stages. It has been argued that accidental clearings occur even if continuous cover forestry is the operational aim due to windthrow or insect outbreaks. However, in Germany, in contrast to "cut and leave", these cleared areas would undergo the cycle of tending and thinning in which the early successional species are removed. Thus, these accidental clearings do not support biodiversity in the same way as "cut and leave".

There are not sufficient georeferenced data to support the suspicion that Romanian forests that had been "cut and left" to succession contain a higher diversity of all organisms than the intensively managed forests in Germany. However, the 
existing observations appear to support the initial hypothesis that the organismic diversity in the Carpathian Mountains as compared to Germany is related to land management and not simply a consequence of a Pleistocene history. A higher species reservoir was even maintained on large-scale clearcuts. Obviously the intermediate disturbance theory (Hobbie et al., 1994) holds, namely that disturbance, regardless of whether it is natural or anthropogenic, promotes biodiversity.

\section{Economic considerations}

Table 2 presents estimated costs and revenues for hypothetical intensive and extensive Fagus and Picea age-class forests. The costs and revenues are based on German data from 2013, disregarding the cost of capital estimates.

In Germany, the tending operation at thicket stage is without net income. For thinning operations, machine access tracks are installed at an age when commercial wood is available. They are spaced every $20 \mathrm{~m}$ (sometimes $25 \mathrm{~m}$ ) of $4 \mathrm{~m}$ width without trees. Thus they in fact create a loss of forest cover. The operational costs for Picea and for Fagus forests refer to a mountain region based on regional prices in Thuringia. Timber prices are higher for Picea than for $\mathrm{Fa}$ gus. Thus, despite higher costs, the net income is about twice as high for Picea than for Fagus.

This budget is compared with the "cut and leave" as in Romania but based on the German economic situation. Forests are left to grow after clear-felling without tending or thinning. The total income in the "cut and leave" mode would be very similar to the intensive operation for Picea, but higher in Fagus. We are aware that this budget is very coarse, and more detailed economic assessments are needed in the future. However, the budget indicates that these sylvicultural systems may be economically similar, because "cut and run" saves thinning cost.

The main difference between intensive and extensive forest management would be the total amount of wood delivered to the market. It would be 10 to $20 \%$ smaller under the "cut and leave" regime. The rotation time would be longer for "cut and leave" (about $100 \mathrm{yr}$ ) than for "intensive" (about $80 \mathrm{yr}$ ), which would reduce the net income of the "cut and leave" mode on similar time axis. However, the "cut and leave" mode would require less maintenance of extraction roads, and lower overheads of management and administration.

The main point of this simple comparison is to show that the economics of management can be quantified, and even if the "cut and leave" mode were to turn out to be less profitable, this disadvantage could be compensated by an increase in diversity. We suggest that, pending on more detailed economic analyses, the extensive "cut and leave" management approach might be more profitable than the intensive management currently practiced in Germany, even when based on German prices.
In this context, we wish to point out that the continuous cover forestry (also known as near-natural forest management in Germany) maintains a permanent forest cover by selective harvesting, minimal human disturbance, avoidance of clear-felling, and the use of natural regeneration of siteadapted tree species. In many regions of the world, continuous cover forestry is believed to be superior to even-aged monocultures in addressing a wide range of expectations (Pukkala and Gadow, 2012). Continuous forestry would be the ideal system on small properties, because thinning cost is reduced and single trees are felled when they have reached a marketable size and whenever income to the owner is needed. However, we feel that continuous forest cover and also selective cutting (Plenterwald) does not fulfill the biodiversity expectations in the same way as the "cut and leave" approach, due to the lack of intermittent larger scale disturbances and the associated lack of early successional stages (data were not presented). The current strategy of wood production in beech forests, which avoids clear-cutting and relies on natural regeneration processes but reduces standing dead wood to low amounts, is insufficient as a conservation-oriented management strategy (Gossner et al., 2013).

\section{Extent and shape of clear-felling areas}

The main question on "cut and leave" management concerns the extent of clear-felling areas to support diversity. Clearly, research is needed to determine the optimum size and shape of clear-felled areas, which could be long narrow strips to allow seeding from the remaining forests alongside (stripcutting). The clear-felled area will depend on the species. Oak will seed directly only over small distances, but may be transported over long distances by jays. Fagus can be regenerated on strip-cuts being about as wide as tree height. Acer, Ulmus, Picea and Pinus can seed over a relatively large distance, and regenerate clear-cuts of several hectares if seed sources are available. Also, the maintenance of old and often stem-rotten "methuselah trees" may be important for the maintenance of metapopulations (Müller et al., 2013; SiiraPietikainen and Haimi, 2009).

Canopy diversity in deciduous and coniferous forest will probably increase initially with increasing size of the clearfelling area, but then reach an optimum and decline. More research and observations are needed. In this context an investigation of the large clear-cuts after World War II in Romania and in Germany would be of interest.

A major problem with the "cut and leave" approach will be how to ensure that the harvested land remains undisturbed for many decades or even for more than a century into the future. 


\section{Conclusions}

There are forest management systems that are both profitable and at the same time contribute to site-specific biodiversity (in contrast to an artificially induced abnormal or unnatural diversity). Win-win situations appear possible, such as using less intensive management approaches like "cut and leave", which have previously been condemned as being unsustainable or even described as deforestation. The optimum size and shape of clear-cut areas remains debatable. However, a "cut and leave" type management, despite its positive effects on biodiversity, may be commercially undesirable, because it would deliver less wood to the timber market. Also, the general public has condemned clear-felling mainly for emotional reasons. Erosion is not a major problem on clear-cuts in temperate climates if slash remains on the harvested area. In view of the uncertainty in our commitment to maintaining forest land undisturbed for a century, the extensive management has some obvious disadvantages, but these disadvantages may be outweighed by the immense beneficial effects on biodiversity. Further research is needed to substantiate this hypothesis.

Acknowledgements. We would like to acknowledge the help of Gheorghe Marin for permission to use the Romanian Forest Inventory Dead Wood data, of Victor Adrian Indreica (Brashov, Romania) for providing the herbaceous flora of the Romanian forests, of Ludwig Leidinger for help with R statistics, of Andreas von Hessberg (Bayreuth, Germany) for providing the bird fauna of Boisoara, of Albert Reif (Freiburg, Germany), and of Waltraud Schulze for many editorial comments. We thank John Gash for English editing.

Edited by: J. Stadler

Reviewed by: two anonymous referees

\section{References}

Aravind, N. A., Manjunath, J., Rao, D., Ganeshaiah, K. N., Shaanker, R. U., and Vanaraj, G.: Are red-listed species threatened? A comparative analysis of red-listed and non-red-listed plant species in the Western Ghats, India, Curr. Sci. India, 88, 258-265, 2005.

Boch, S., Prati, D., Müller, J., Socher, S., Baumbach, H., Buscot, F., Gockel, S., Hemp, A., Hessenmöller, D., Kalko, E. K. V., Linsenmair, E., Pfeiffer, S., Pommer, U., Schöning, I., Schulze, E. D., Seilwinder, C., Weisser, W. W., Wells, K., and Fischer, M.: High plant species richness indicates management-related disturbances rather than conservation status of forests, Basic Appl. Ecol., 14, 496-404, doi:10.1016/j.baae.201306001, 2013.

Bosch, J. and Gadow, K. v.: Regulating Afforestation for Water Conservation in South Africa, South African Forest Journal, 153, 41-54, 1990.

Brändle, M. and Brandl, R.: Species richness of insects and mites on trees: Expanding Southwood, J. Anim. Ecol., 70, 491-504, 2001.
Burschel, P. and Huss, J.: Grundriss des Waldbaus, 3. Auflage, Ulmer Verlag, Stuttgart, 487 pp., 2003.

Bussler, H. and Müller J.: Es gibt sie doch - die guten und die schlechten Wälder. Wir brauchen differenzierte Konzepte im Waldnaturschutz, AFZ-DerWald, 4, 174-175, 2006.

Bussler, H., Müller, J., and Dorka, V.: European natural heritage: The saproxylic beetles in the proposed parcul, National Defileul Jiului Anale, ICAS, 48, 55-71, 2005.

Chumak, V., Duelli, P., Rizun, V., Obrist, M. K., and Wirz, P.: Arthropod biodiversity in virgin and managed forests in Central Europe, Forest Snow Landscape Research, 79, 101-109, 2005.

Commarmot, B., Bachofen, H., Bundziak, Y., Bürgi, A., Ramp, B., Shparyk, Y., Sukhariuk, D., Viter, R., and Zingg, A.: Structures of virgin and managed beech forests in Uholka (Ukraine) and Sihlwald (Switzerland): a comparative study, Forest Snow Landscape Research, 79, 45-56, 2005.

Dragoi, M. and Ciornei, I.: A black-box approach on assessing the opportunity cost of deforestation, Land Use Policy, 34, 314-320, 2013.

FAO: Towards sustainable forest management: an examination of the technical, economic and institutional feasibility of improving management of the global forest estate. Working Paper prepared for the World Bank Forest Policy Implementation Review and Strategy by Arnoldo Contreras-Hermosilla, FAO, Forestry Policy and Planning Division, Rome, 66 pp., 1999.

Finch, O. D.: Evaluation of mature conifer plantations as secondary habitat for epigeic forest arthropods (Coleoptera: Carabidae, Araneae), Forest Ecol. Manag., 204, 21-24, 2005.

Forest Code: Law $\mathrm{Nr} 46 / 2008$ on the Forest Code (Legea $\mathrm{Nr}$ 46/2008 Codul silvic), Moniturul Oficial, Partea I Nr 238/27 martie, 2008.

Glastra, R.: Cut and run: illegal logging and timber trade in the tropics, International Development Research Centre, 112 pp., 1999.

Gossner, M. M., Lachat, T., Brunet, J., Isacsson, G., Bouget, C., Brustel, H., Brandl, R., Weisser W. W., and Müller, J.: Current near-to-nature forest management effects on functional trait composition of saproxylic beetles in beech forests, Conserv. Biol., 27, 605-614, 2013.

Greenpeace, Forest Cover changes in Romania in 2000-2011, http://www.greenpeace.org/romania/global/romania/paduri/ despaduririle $\% 20 \mathrm{din} \% 20$ Romania/forestcover\%20change $\%$ 20in\%20Romania\%202000-2011.pdf, 2012.

Hacker, H.: Schmetterlinge und Sträucher, in: Sträucher in Wald und Flur, edited by: Bayerischer Forstverein, Ecomed, Landsberg, 510-520, 1998.

Hobbie, S. E., Jensen, D. B., and Chapin III, E. S.: Resource supply and disturbance as control over present and future plant diversity, Ecological Studies, 99, Springer, Heidelberg, Germany, 385-408, 1994.

Küster, H.: Geschichte des Waldes. Von der Urzeit bis zur Gegenwart, 2. Auflage, Beck Verlag, Munich, Germany, 267 pp., 2008.

Lüpke, N. v., Hardtke, A., Lück, M., Hessenmöller, D., Ammer, C., and Schulze, E. D.: Bestandesvorrat, Baumartenvielfalt und Strukturkleinparzellierter Privatwälder im Hainich, Forstarchiv, 82, 203-215, 2011.

Meyer, P. and Schmidt, M.: Accumulation of dead wood in abandoned beech (Fagus sylvatica L.) forests in northwestern Germany, Forest Ecol. Manag., 261, 342-352, 2011. 
Müller, J., Bussler, H., and Dorka, V.: Karpatenwälder als Bezugsflächen für mitteleuropäische Urwälder, AFZ-Der Wald, 9, 482484, 2005.

Müller, J., Engel, H., and Blaschke, M.: Assemblages of woodinhabiting fungi related to silvicultural management intensity in beech forests in southern Germany, Eur. J. For. Res., 126, 513527, 2007.

Müller, J., Jarzabek-Müller, A., Bussler, H., and Gossner, M. M.: Hollow beech trees identified as keystone structures for saproxylic beetles by analyses of functional and phylogenetic diversity, Anim. Conserv., doi:10.1111/acv12075, 2013.

Paillet, Y., Bergès, L., Hjältén, J., Odor, P., Avon, C., BernhardtRömermann, M., Bijlsma, R. J., de Bruyn, L., Fuhr, M., Grandin, U., Kanka, R., Lundin, L., Luque, S., Magura, T., Matesanz, S., Mészáros, I., Sebastià, M. T., Schmidt, W., Standovár, T., Tóthmérész, B., Uotila, A., Valladares, F., Vellak, K., and Virtanen, R.: Biodiversity Differences between Managed and Unmanaged Forests: Meta-Analysis of Species Richness in Europe, Conserv. Biol., 24, 101-112, 2009.

Popescu, G., Patrascoiu, N., and Grigorescu, V.: Padurea Si Omul, Editura Nord Carta, Suceava, Romania, 602 pp., 2004.

Pukkala, T.: Integrating multiple services in the numerical analysis of landscape design, in: Designing Landscapes, edited by: Gadow, K. and Pukkala, T., Springer Verlag, 137-168, 2008.

Pukkala, T. and Gadow, K. v. (Eds.): Continuous Cover Forestry, Book Series Managing Forest Ecosystems, 24, Springer Science+Business Media B.V., 324 pp., 2012.

Reif, A., Schulze, E. D., Ewald, J., and Rothe, A.: Waldkalkung - Bodenschutz contra Naturschutz, Waldökologie, Landschaftsforschung und Naturschutz, urn:nbn:de:0041-1fsr-01423, in press, 2014.

Renner, S. C., Baur, S., Possler, A., Winkler, J., Kalko, E. K. V., Bates, P. J. J., and Mello, M. A. R.: Food preferences of winter bird communities in different forest types, PLOS One, 7:e53121, 2012.

Renner, S. C., Gossner, M. M., Kahl, T., Weisser, W. W., Fischer, M., and Allan, E.: Temporal changes in randomness of bird communities in forests and grasslands across Central Europe, J. Anim. Ecol., submitted, 2013.
Schmidt, W.: Biotische Mannigfaltigkeit - Indikator für intakte Wälder? Beispiel aus Studien über Bodenvegetation in Naturwaldreservaten, NUA, 4, 108-127, 2000.

Schulze, E. D., Hessenmöller, D., Seele, C., Wäldchen, J., and Lüpke, v. N.: Die Buche: Eine Kultur- und Wirtschaftsgeschichte, Biologie in unserer Zeit, 3, 171-183, 2010.

Schulze, E. D., Wäldchen, J., Bouriaud, O., Walentowski, H., Seele, C., Heinze, E., Pruschitzki, U., Danila, G., Marin, G., Hessenmöller, D., Bouriaud, L., Teodosiu, M., and Eisenhauer, N.: Deciduous forest species composition in Germany and Romania in relation to management and ungulate browsing, Forest Ecol. Manag., submitted, 2013.

Siira-Pietikainen, A. and Haimi, J.: Changes in soil fauna 10 years after forest harvestings: Comparison between clear felling and green-tree retention methods, Forest Ecol. Manag., 258, 332338, 2009.

Waldbaurichtlinie, Waldbaugrundsätze für den Staatswald Thüringens einschließlich der Behandlungsrichtlinien der Hauptbaumarten, GE Nr 3/2004, 29 June 2004.

Walentowski, H., Bussler, H., Bergmeier, E., Blaschke, M., Finkeldey, R., Gossner, M. M., Litt, T., Müller-Kroehling, S., Philippi, G., Pop, V. V., Reif, A., Schulze, E. D., and Wirth, V.: Sind die deutschen Buchenwälder adäquat für die Erhaltung der buchenwaldtypischen Flora und Fauna? Eine kritische Bewertung basierend auf der Herkunft der Waldarten des mitteleuropäischen Tief- und Hügellandes, Forst Archiv, 81, 195-217, 2010.

Walentowski, H., Schulze, E. D., Teodosiu, M., Bouriaud, O., Heßberg, v. A., Bußler, H., Baldauf, L., Schulze, I., Wäldchen, J., Böker, R., Herzog, S., and Schulze, W.: Sustainable forest management of Natura 2000 sites: a case study from a private forest in the Romanian southern Carpathians, Annual Forest Research, 56, 217-245, 2013. 